\title{
BUONARROTI'S IDEAS ON COMMUNISM AND DICTATORSHIP
}

Le nom seul de Buonarroti est ume doctrine. Franzinetti, in „Le Radical”, 24.9.1837.

At the University of Pisa, where he studied law, Buonarroti had been acquainted with the 18 th century social philosophers especially Helvetius, Mably, Rousseau and Morelly, who had moulded his social and political ideology. When the French Revolution broke out he was among the most courageous protagonists to defend its ideas: "J'attendais depuis longtemps le signal, il fut donné". In October 1789 he left his native Tuscany, "ivre de l'amour de la liberté, épris de la courageuse entreprise des Français, indigné contre la tyrannie, et las de l'inquisition et des persécutions du despotisme", as he said later in his defence at Vendôme. In Corsica he published an Italian paper in defence of the French Revolution, the Giornale Patriottico ${ }^{1}$, and in November 1790 he obtained a post in the administration of the island as head of the "Bureau des domaines nationaux et du clergé". In this capacity he had to deal with the administration and sale of landed property. The rural economy of the island was based on a nearly equal distribution of very small holdings, there were hardly any labourers, and there existed a strong tradition of common interests and collective rights. In his Survey of Corsica Buonarroti wrote: "La communalité des biens semble garantir partout au pauvre le sentiment

1 The only complete copy known to exist is now in the Biblioteca Feltrinelli, Milan. Most biographical articles mention an Italian paper, l'Amico della Liberta Italiana, edited by Buonarroti in Corsica. This is obviously the Giornale Patriottico. Ambrosi in his "Notice sur Buonarroti", however, mentions a Tuscan paper, L'Ami de la liberté Italienne (Bulletin de la Société des Sciences Historiques et Naturelles de la Corse, Bastia 1919, No. $389-392$, p. 2). Buonarroti said at his trial at Vendôme: „En $I 787$ je fus le rédacteur d'un journal français qui proclamait déjà les principes de la liberté, En 1788, et au commencement de 1789 , je publiais dans quelques articles d'une feuille italienne l'éloge de la révolution française". (Débats du procès instruit par la Haute-Cour de Justice, Paris, $\mathrm{I} 797$, IV, p. 294). There is as far as I know no Italian source referring to a French paper, but a further Italian research may settle this point. Buonarroti had been an editor in 1788 and 1789 of an Italian paper, the Gazette Universale in Florence. 
de son indépendance: partout les communes des campagnes réclament des biens que la tyrannie génoise et française ravit au peuple pour récompenser les crimes de ses favoris. Les grands propriétaires sont en très petit nombre: l'homme sans terre est rare, comme celui sans courage". 1

Alessandro Galante Garrone has stressed the fact ${ }^{2}$ that the social and economic structure Buonarroti found in Corsica may have influenced his communist ideas. There is, however, nothing in Buonarroti's writings during his Corsican years (1789-1 793 ) nor in fact in the subsequent years (till 1796 ) which suggests that his notions about private property may have gone beyond the Rousseauist ideal of equality. The text of tize Constitution, a "Code de la Nature", which he framed for the small island of St. Pierre - an episode during the illfated expedition (Jan.-Febr. 1793) for the conquest of Sardinia, which he had joined as an "apôtre de la liberté" - is still unknown. It seems however most unlikely that his ideas about property were different from those Robespierre was to defend two months later in his proposed Declaration of Rights.

After his arrival in metropolitan France in March 1793 he joined the Jacobin Club ${ }^{3}$ in Paris. During his stay in the capital in the following months he witnessed the Revolution as it reached its most critical and dramaticstage: the "journée" of the 2nd of June, the fall of the Girondins, the creation of the Committees of Public Safety and General Security, the establishment of the dictatorship of the Montagne and of the Jacobins. Probably through Saliceti whom he knew from Corsica and whom he might have known already during his studies at Pisa, he became acquainted with Jacobin leaders like Ricord, Vadier,Laignelot; he certainly met Robespierre - whose ideas of a republic of virtue and the cult of a social religion he shared, and for whom he preserved a great veneration throughout his life - although their personal relationship is still somewhat obscure. ${ }^{4}$

1 La Conjuration de Corse, 1793 , p. $27 \cdot 28$.

2 Alessandro Galante Garrone, Buonarroti e Babeuf, Torino, 1948, p. 52-67.

${ }^{3}$ He spoke in the Jacobin Club during his stay in Paris. Aulard however does not mention him in his Société des Jacobins. Buonarroti had become a member of the Jacobin Club at Corte in 1792.

4 Lamartine in his Histoire des Girondins (Livre XXX, ch. I3) relates that Buonarroti belonged to Robespierre's intimate circle. The statement is based on information of Madame Lebas (one of the daughters of Maurice Duplay, the host of Robespierre) and her son Philippe. They corrected the first version of Lamartine's story and gave Buonarroti's name amongst those who visited Robespierre "always", with Lebas, Saint-Just, David, Couthon (c.f. Stéphane-Pol, Autour de Robespierre, le Conventionnel Lebas..., Paris [1901], p. 84).

(Note 4 continued on page 268 ). 
In July 1793 he became a "Commissaire" of the Government, and from April 1794 to March 1795 he was in charge of the administration of the Italian principality of Oneille, occupied by French troops. His experience as an administrator had a profound influence on his opinions. Until then an enthusiastic protagonist of the French Revolution, he became critical of certain of its more concrete results and he came to the conclusion that new methods had to be thought out (Dec. 1794). ${ }^{1}$ Buonarroti was still at his post at Oneille when Robespierre fell. Eight months later, however, on the 5 th March 1795 , he was arrested, sent to Paris and imprisoned in the Du Plessis. There he met Babeuf and many Robespierristes and "Hébertistes", all victims of the post-Thermidorian reaction. Released on 9th October 1795 , a few days after the royalist uprising of Vendémiaire, Buonarroti started the fight against the post-Thermidorian regime. The Jacobin clubs, which had been closed after Thermidor - most "Sociétés Populaires" were already closed before Thermidor - were again tolerated with certain restrictions mainly with the aim of strenghthening the Government against the royalist menace. The "Société de la Réunion des Amis de la République", known as the "Société du Panthéon", founded in December 1795, was used by Buonarroti and his friends for their own aims until it became obvious that it had become a rallying-place of all opponents of the Government: the club, presided over by Buonarroti, was closed by order of the Government on $27^{\text {th }}$ February. A few weeks later, under the leadership of Babeuf, a Committee which styled itself the Secret Directory was formed to prepare an insurrection to overthrow the Government. Two papers, Babeuf's Tribun du Peuple and L'Eclaireur du Peuple, edited by

With regard to Hamel's statement that Buonarroti played the piano in the family circle, J. M. Thompson (Robespierre, 1935, I, p. I86-187) remarks that it may be only Hamel's guesswork that places the piano there, and that it is difficult to separate fact from fiction in the accounts of Robespierre's daily life. Hamel's statement is probably based on Buchez et Roux and the piano is already there: "C'était dans l'intérieure de cette famille patriarche que Robespierre passait toutes ses soirées. Lebas, amateur passionné de la musique italienne, qu'il chantait fort agréablement, se faisait souvent entendre dans cette réunion interne ou Ph. Buonarroti tenait le piano" (Histoire Parlementaire, vol. 35, I 837, p. 34I). Buchez knew Buonarroti and got information from him (c.f. Histoire Parlementaire, Vol. 34, 1837 , p. 3, 4). Buonarroti never spoke about his relations with Robespierre, but those who knew him, like Prati, Rusconi, Raspail, etc., mentioned this association. Raspail related in his Lettres sur les prisons de Paris (Paris, I 838, II, p. 323) that Buonarroti spoke of Robespierre as "son terrible et vertueux ami". On the other hand Buonarroti is recorded to have said: "Je ne connus pour ainsi dire pas Maximilien Robespierre" (Buonarroti, a biographical article in the Almanach de la France démocratique, 1846, p. 87-89).

1 Pia Onnis, Filippo Buonarroti Commissario rivoluzionario a Oneglia nel 1794-95, I939, p. 4I. 
Simon Duplay, were at the disposal of the Committee, which developed a feverish activity in publishing pamphlets, posters and tracts. A secret network of agents, one for each arrondissement, was organised "to guide public opinion" by distributing and discussing the literature issued by the Committee, and to keep the Committee informed. "Military agents" were to do a similar job amongst the troops.

The insurrection aimed at a return to the Revolutionary Government,

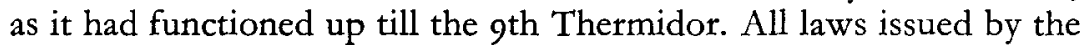
post-Thermidorian government and the Directoire were to be repealed and the Constitution of the year III, voted in December 1795 , replaced by that of 1793. Although in the opinion of the "Egaux" the great fault of that constitution was the article concerning private property, the constitution was to be retained, as the argument ran, because of "the almost unanimous sanction it had received from the nation" 1 and because it stated the right of the people to deliberate on the laws ${ }^{2}$, which according to Buonarroti was its essential feature. The constitution in fact provided a kind of direct legislation, even of direct government: certain acts, e.g. declarations of war, civil and criminal laws, acts affecting public education and taxation, could not come into effect if they were vetoed by the primary assemblies. On the roth August 1793 this democratic constitution providing for universal suffrage had been proclaimed, but it had been postponed by the decree of the 1oth October 1793, and the provisional Government was declared valid "jusqu'à la paix". Restoration of the constitution of 1793 became the most important propaganda slogan. ${ }^{3}$ Posters were issued with the text: "Constitution de I 793. Liberté, Egalité, Bonheur Commun". In the political programme published on the 2oth Germinal (9th April 1796) under the title Analyse de la doctrine de Babeuf, it was said: "The Constitution of 1793 is the veritable law of the French, because the people has solemnly accepted it; because the Convention had not the right to change it, ... because the Constitution of 1793 has consecrated the inalienable right of every citizen to consent to the laws..." The point was elaborated in two pamphlets "Opinions sur nos deux constitutions", published on the 23 rd Germinal, and "Doit-

1 Ph. Buonarroti, Conspiration pour l'Egalité dite de Babeuf, Bruxelles, I828, I, p. I I 9. In the following quoted as "Conspiration".

2 The main difference between the two constitutions, Buonarroti wrote, was that the Constitution of 1793 implied that "nulle loi ne peut être imposée au peuple sans son consentement explicite" and that the one of 1795 created "des législateurs indépendants du peuple"; c.f. The Memoir "Au Gouvernement de la République française" [the Consulate] dated ${ }_{24}$ Pluviose An VIII. Arch. Nat. $\mathrm{BB}^{3} 2$ I.

3 The spontaneous popular insurrection of the Ist Prairial against the post-Thermidorian government had equally as its main slogan Bread and the immediate application of the Constitution of 1793 . 
on obéissance à la Constitution de 1793 ?", published two days later, written by Buonarroti. This propaganda also provided a platform for a united action with a group of former Jacobin deputies, expelled from the Convention after Thermidor and declared ineligible for the new National Assembly, the "Cinq Cents". These former "Montagnard" deputies were also conspiring against the Government with a view to a return to the pre-Thermidorian Convention. Amongst them were Robert Lindet, a former president of the Convention, members of the Committee of General Security like Amar and Vadier and "représentants en mission" like Ricord, Laignelot and Choudieu.

Immediately after the successful outcome of the insurrection the revolutionaries in Paris, "the citizens who had first taken up arms", were to meet in assembly on the "Place de la Révolution", where the Secret Directory would render an account of its activities. It would then be acclaimed by the assembly as the Revolutionary Government, and the same popular assembly would nominate a National Assembly composed of one democrat for each Department. Those to be appointed were already on a list which had been prepared by Buonarroti. But the conduct of this Assembly would be watched over by the Revolutionary Government of Public Safety, which would "remain en permanence until the complete accomplishment of the insurrection". The former "Montagnard" deputies, however, insisted that the preThermidorian Convention should immediately reassemble and resume its functions. This was originally rejected by Babeuf's Committee, but under pressure from the generals of the Military Committee, who thought that their authority as former administrators and their popularity as prominent victims of the post-Thermidorian reaction was essential to the success of the insurrection, and in view of the precarious situation an agreement was reached. ${ }^{1}$ This laid down that the National Convention should be recalled but should be composed exclusively of the proscribed deputies together with the members on Buonarroti's list. At the same time the "Montagnards" agreed with the measures proposed by Babeuf's Committee. Nevertheless it was an uneasy coalition. Both parties may have thought using each other for their own purposes, although Buonarroti gives the impression that some of the "Montagnards" like Amar and Lindet had accepted the equalitarian programme. The opinion of Mathiez ${ }^{2}$ that the Babouvist

1 If one realises that several of the "Montagnards" like Amar and Vadier had been Thermidorians, the opposition in the Committee of Babeuf is easily understood. One of the members, Debon, even declared that he would prefer renouncing the entire plan of an insurrection rather than associate it with these "Montagnards".

2 Albert Mathiez, Le Directoire. Paris, 1934, p. 212. 
conspirators were only a tool in the hands of the ex-"Montagnards" and that the conspiracy was "beaucoup moins une tentative communiste qu'un dernier effort des terroristes pour ressaisir le pouvoir" is difficult to sustain. It is true that the Babouvists wanted to reinstate the Jacobin administration, but their ultimate aim was to use this administration for the carrying out of their revolutionary plans. Had the insurrection succeeded, it might well have resulted in the restoration to power of the Jacobin politicians. Babeuf, however, thought that the pressure of the popular movement - another Io Août - would keep the political influence of the "députaille" and "politicaille" in check. In a message to its agents the Secret Directory had violently attacked the former members of the Convention: "Ces hommes ont bu dans la coupe du pouvoir; ils ne se sont pas montrés tous et toujours rigoureusement démocrates. Il faut des hommes neufs; il faut des hommes purement sans-culottes, de vétitables hommes du peuple... c'est pourquoi le No. 42 du Tribun du Peuple, qui parait en même temps que cette circulaire et qui roule uniquement sur cet objet... peut être considéré comme une instruction faite à cet égard à tout le peuple... c'est dépopulariser ces hommes dangereux qu'il faut absolument faire." 1

The whole enterprise was questionable but not at all utopian. ${ }^{2}$ It cannot reasonably be doubted that the Government was in danger. ${ }^{3}$

1 Copie des Pièces, II, p. 171-172. In the article Un mot pressant aux Patriotes, published in the Tribun du Peuple du 24 Germinal an IV, Babeuf wrote: "Le Peuple, ne se lèvera qu'en masse et à la voix de ses véritables libérateurs... Les gouvernants ne font des révolutions que pour toujours gouverner. Nous en voulons faire enfin une pour assurer à jamais le bonheur du Peuple par la vraie démocratie" (Maurice Dommanget, Pages choisies de Babeuf, Paris 1935, p. 291 and 293).

2 The propaganda under the troops in the capital, the so-called "Légion de Police"organised in the days after Prairial - had not been unsuccessful. The Government aware of their unrest, decided to send them to the frontier. The "Légion" mutinied and it seems that this should have been the signal for the insurrection. Instead the Government did the decisive tactical move: the men of the "Légion", who were to have formed the shock troops for the insurrection, were dismissed. As not unusual under those circumstances the situation had gone out of hand. Where there is no question of a "pronunciamento", a "coup d'état", but of an insurrection based on a popular movement, the "thermometer" cannot be regulated like a watch. The governmental move to send the "Légion" away from Paris had set of the mutiny the Secret Directory had prepared, but it came before all the preparations were complete and they hesitated to launch the insurrection. Instead of taking the offensive they waited and were defeated. It seems that this might have been their decisive chance, whatever the outcome: even thirty years later Buonarroti held that the insurrection would have been successful without the treason of Grisel, which led to his arrest ( 10 May ${ }_{79}$ ), his subsequent trial, imprisonment and exile.

${ }^{3}$ Many historians denied this, although nobody went so far as Advielle, who denied that there was a real plan for the insurrection because the accused denied it - an opinion which is plainly absurd. 
The purpose of the plot was however not only a Jacobin "coup d'état" in disguise, but a social revolution as well. Mathiez' opinion that Babeuf's communism "est quelque chose de purement accessoire qui intéresse peu sa vraie politique" is not altogether substantiated. There cannot be any doubt about Babeuf's communist ideas. Babeuf had read Rousseau and Mably, and his experience as a "feudiste" and in general the particular agricultural situation of his native Picardy, might have influenced his ideas". ${ }^{1}$ The abolition of feudal rights had not much improved the situation of the poor farmers and Babeuf in I79I saw the solution in an equal redistribution of land, in other words in the "Loi Agraire". ${ }^{2}$ As inheritance would be abolished and the community would become the proprietor of the land, there would be no private property but only the right of use of land. The harvest would be common property and even with individual working of the land an agrarian communism would be established, a communism based on equal partition and community of goods. Babeuf had however changed his opinion about the "Loi Agraire" and in 1796 he advocated an agrarian communism no longer based on the partition of land. "Est-ce la loi agraire - Babeuf wrote in his Tribun du Peuple ${ }^{3}$ - que vous voulez, vont s'écrier mille voix d'honnêtes gens? Non: c'est plus que cela. Nous savons quel invincible argument on aurait à nous y opposer. On nous dirait, avec raison, que la loi agraire ne peut durer qu'un jour; que, dès le lendemain de son établissement, l'inégalité se remontrerait. Les Tribuns de la France, qui nous ont précédés, ont

1 See in this connection the Introduction of Georges Lefebvre to M. Dommanget's Pages Choisies, op. cit., p. VII-XI, and Georges Lefebvre, Les origines du communisme de Babeuf, in his Etudes sur la Révolution Française, Paris, 1954, p. 305-314.

2 The expression was derived from Roman history (partition of the conquered lands) and meant in a somewhat vague way an agrarian revolution, expropriation and parcelling of the land on behalf of the cultivators. On rgth March 1793 the Convention decreed quasi unanimously the death penalty "contre quiconque proposera une loi agraire ou toute autre, subversive des propriétés territoriales, commerciales et industrielles". Although motivated as a measure against the counter-revolutionists the real purpose was to assure the "acquisitateurs" of the "biens nationaux" of their property. In fact the death penalty was decreed for those who attacked the principle of private property. "Equality" was an innocent word, but propaganda for the "Loi Agraire" became the essential crime against society. In the last resort it was for this that Babeuf was brought to the guillotine. "Quel horrible bouleversement que l'anéantissement de ce droit de propriété, base universelle et principale de l'ordre social", exclaimed Viellart, the "accusateur national" at Vendôme. Attacking private property remained a dangerous crime for more than thirty years and only after the July-revolution communism could be openly propagated. Even in the secret societies during these years these ideas could only be held or expressed by its most secret circle. This is the essential significance of the "credo" of the "Areopagus" of Buonarroti's "Sublimes maitres parfaits".

${ }^{3}$ No. 35, 3oth November I795, quoted from M. Dommanget, Pages Choisies, op. cit., p. 255 . 
mieux conçu le vrai système du bonheur social. Ils ont senti qu'il ne pouvait résider que dans des institutions capables d'assurer et de maintenir inaltérablement l'égalité de fait".

From the documents Buonarroti prepared in connection with the conspiracy in April-May 1796 it is evident that he shared these ideas, and although still a convinced Robespierrist he then advocated for the first time the abolition of private property and the community of goods. In his "Réponse à une lettre signée M.V." 1 Buonarroti wrote: "The system of equality excludes all division". ${ }^{2}$ It is this very division that has caused all the evils of society, and to remedy them all the existing wealth of the country should be placed in the hands of the Republic; and all agricultural and industrial products should be deposited in public stores. Private property should be abolished and replaced by an equal distribution. Thus real equality would be based on two essential conditions: work in common and enjoyment in common. Every individual would work for the community and would have in return security of livelihood and should get a fair share of the "general pleasure and happiness". Thus equality would not be a chimera and the liberty of every individual would be assured.

In more general terms the programme of the conspirators was published as a tract of four pages and placarded in three hundred posters under the title "Analyse de la doctrine de Babeuf"; this is less a summary of the doctrine than a political manifesto and it is moderate in its communist aims. The purpose of society is to defend equality: labour and recreation ought to be common; in a true society there ought to be neither rich nor poor; the rich who are not willing to renounce their superfluous wealth in favour of the poor are the enemies of the people.

The "Explanation and proofs" - which only became known through publication in Buonarroti's book in I 828 - of some of the articles of the "Analysis" reflect more the real communist aims than the text of the pamphlet distributed in May 1796. Art. VI of the "Analysis" ran: "Nobody could, without crime, exclusively appropriate to himself, the goods of the earth or of industry". In the "Explanation" was added: "From the moment lands were divided arose the exclusive

1 A pamphlet of eight pages, published on the 28th Germinal.

2 M.V. (according to G. Walter, "Babeuf", Paris, 1937, p. 185, the author is Marc Vadier) had questioned Babeuf's theory of equality and had remarked: "The difficulty of the question lies not merely in the division of lands but in providing that such a division be durable", in a letter "A Gracchus Babeuf" Tribun du Peuple de l'Imprimerie de l'Ami du Peuple (R. F. Lebois) 3 pp. In the list of contents of the Conspiration Buonarroti mentions the letter under the heading "Lettre à Babeuf, contenant des doutes sur le système de la communauté." 
right of property. ${ }^{1}$ Misery and slavery are consequences of inequality, which is itself the result of property. Property is therefore the greatest scourge of society; it is a veritable public crime". ${ }^{2}$ These communist aims are also more explicit in the Manifeste des Egaux, written by Sylvain Maréchal ${ }^{3}$, one of the members of the Secret Directory. This contains an excellent exposition of their programme, and is fundamentally identical with the afore-mentioned article by Babeuf. "We aim at something more sublime and more equitable [than the "Loi Agraire" or partition of lands], we look to common property, or the community of goods! No more individual property of the land. The earth belongs to no one. We claim, we want the communal enjoyment of the fruits of the earth: the fruit belongs to all". This Manifesto was however not accepted by the Committee and it was not printed ${ }^{4}$; instead the "Analysis" was published, and the Manifesto only became known through the publication of the seized documents, after which it was often reprinted. Buonarroti said that the passages: "Perish, if needs be, all the arts, provided real equality abides with us!" and "Away for ever with the revolting distinctions of governors and governed" were not approved. He never explained, however, why these two passages were not changed or removed, and why the Manifesto was not printed at all. The Manifesto might have been regarded as too long and too philosophical or perhaps the communist aims were too explicit for the propagandistic purpose it had to serve.

Most of the equalitarian ideas had of course been formulated by the I 8 th century philosophers, especially Mably and Morelly, and many of the proposed measures had been advocated during previous years. Morelly formulated in his "Code" the three fundamental and sacred

1 The "credo" of the highest grade, the "Areopagus", of Buonarroti's "Sublimes Maitres Parfaits" read: "From the imprudent division of the land all crimes, vices and hatred have sprung". (c.f. "Buonarroti and his international secret societies" in this Review, Vol. I, p. 124).

2 "La propriété est la mère de tous les crimes", Morelly wrote in his Basiliade.

3 Why Maréchal was not arrested - although there was a "mandat d'arrêt" dated 24 Floréal (Arch. Nat. $\mathrm{F}^{7} 4^{276}$ ) - nor accused, has never been explained. His name was mentioned in the confiscated documents. Maurice Dommanget, who is an authority on Maréchal as well as on Babeuf, dealt with this problem in Chapter XII of his biography Sylvain Maréchal, l'égalitaire, l'homme sans Dieu, Paris, 1950. His explanation seems neither conclusive nor convincing.

${ }^{4}$ M. Dommanget, op. cit. p. 322, quotes a passage of the circular of the 14 th Floréal of Babeuf to the agents concerning a distribution of a manifesto and concludes: "cela signifie que les conjurés jugèrent bon d'utiliser le Manifeste après l'avoir amputé sans doute des mots jugés subversifs". This conclusion is however erroneous as the quoted passage (c.f. "Copie des Pièces," I, p. I 86, 65 e pièce, 7e liasse) refers not to the Manifesto of Maréchal, but to the Insurrectional Act ("Acte d'Insurrection", printed in: Copie des Pièces, II, p. 244-252; "Conspiration", II, p. 244-253). 
laws "qui couperaient racine aux vices et à tous les maux d'une société" as follows: “Rien dans la Société n'appartiendra singulièrement ni en propriété à personne, que les choses dont il fera un usage actuel, soit pour ses besoins, ses plaisirs, ou son travail journalier. Tout Citoyen sera homme public sustenté, entretenu et occupé au dépens du Public. Tout Citoyen contribuera pour sa part à l'utilité publique selon ses forces, ses talents et son âge; c'est sur cela que seront réglés ses devoirs, conformément aux Loix distributives". 1 The "enragé" Jacques Roux had advocated public stores as a solution for the food problem. One of the "curés rouges", Pierre Dolivier ${ }^{2}$ in his Essay sur la justice primitive (1793), which is summarized by Jaurès, had opposed the "Loi Agraire" and the parcelling of land, and had advocated common property in land; others had held that commerce should be socialized. Although many of the measures which the Revolutionary Government had taken, like the forced loans, the requisitions, the taxes, the regulation of external trade, the maximum, the organisation of armament factories - the whole complex of state intervention in economic affairs - served to show how the state could be used in changing property relations, Buonarroti was well aware that they were mainly emergency measures to meet the necessities of the war and the civil war. As a matter of fact he had opposed many of these measures when he was a pro-consul at Oneille. Mme Pia Onnis thinks that Buonarroti's protests against the requisitions and other measures were not only a consequence of their abuse by the military. ${ }^{3}$ The situation of the poor peasants and the unemployment of the workers of the requisitioned factories in his region led him to question the economic measures which had been applied under the Terror. ${ }^{4}$ From this time onward he probably held the opinion that this kind of measures could not solve the problem of inequality and that the solution was to be found in a community of goods and labour. Buonarroti always

1 Code de la Nature, 1755, p. I 90 . In his "Basiliade" Morelly wrote: "les lois éternelles de l'univers sont que rien n'est à l'homme en particulier que ce qu'exigent ses besoins actuels, ce qui lui suffit chaque jour pour le soutien ou les agréments de sa durće; le champ n'est point à celui qui le laboure, ni l'arbre à celui qui y cueille des fruits, il ne lui appartient même des productions de sa propre industrie que la portion dont il use; le reste, ainsi que sa personne, est à l'humanité" (quoted from Villegardelle, Code de la Nature, Paris, $184 \mathrm{I}$, p. $185-186)$.

2 Pierre Dolivier was on Buonarroti's list as a member to be appointed for the National Assembly. A copy of his pamphlet was amongst the confiscated papers (Arch. Nat. $F^{7} 4247$ ).

3 "Il est prouvé par ma correspondance, et par une infinité de faits notoires dans le pays... que j'ai été continuellement l'effroi des agents des administrations militaires, qui pillaient, maltraitaient et terrifiaient les habitants: que j'ai fait arrêter ceux qui étaient prévenus de pillage et de vexations". "Réponse de Philippe Buonarroti... aux Motifs de son arrestation". A Paris maison d'arrêt du Plessis, ce 12 Messidor l'an 3. (Arch. Nat. F7 6331).

4 C.f. Pia Onnis, Ancora su F. Buonarroti (Nuova Rivista Storica, I955, Fasc. 3). 
maintained that the ultimate aim of Robespierre's policy and the measures of the Committee of Public Safety had such an equalitarian society in view. ${ }^{1}$ Especially in the distribution of lands promised to the defenders of the country, and in the decree which ordained the division among the poor, of the goods of the enemies of the Revolution - the application of the laws of Ventôse - and in the confiscation of the possessions of the counter-revolutionaries, Buonarroti saw not a mere fiscal measure but the vast plan of a regenerating reformer. Many years later Buonarroti wrote that Robespierre's attempt to modify the laws of property had increased the number of his enemies. ${ }^{2}$ This was also the well-known thesis of Albert Mathiez a century later. "Le triomphe de Robespierre en Thermidor - he wrote - eût procuré l'application des lois de Ventôse, c'est-à-dire fait succéder une révolution sociale à la révolution politique". Thus Robespierre, according to Mathiez, had gone beyond political democracy ${ }^{3}$ and was on his way to social revolution and this was one of the causes of his downfall.

Robespierre and St. Just aimed certainly not at the establishment of communism, but at a realisation of Rousseau's ideal, a republic of small landowners and artisans. Even if the laws had been applied they would not have solved the agrarian problem nor would they have been of much importance for the agrarian proletariat, as Georges Lefebvre in his study on this subject has made clear. ${ }^{4}$ Besides, the liquidation of the "enragés" and the "Hébertistes" and the dissolution of the popular societies had undermined the support for the implementation of such

1 This obviously wrong interpretation of a socialist Robespierre played an important rôle in the revolutionary and republican propaganda in the early eighteenthirties.

2 "If we are to believe some of his proscribers, the disposition avowed by Robespierre to modify the laws of property, contributed in no small degree to swell the number of his encmies", Buonarroti wrote in his Observations sur Maximilien Robespierre, written probably in 1833 and published in Le Radical, Brussels (1837, Nr. 33 and 34 , preceded by a note of Delhasse) and republished in La Fraternité (1842) and La Belgique Démocratique $(1851)$. A manuscript of this biographical article was sent to O'Brien in 1836 who published the translation in his The Life and Character of Maximilian Robespierre... ( 1837, p. 83-96). O'Brien said the manuscript has been since (i.e. $18{ }_{3} 6$ ) printed in Paris and largely distributed amongst friends. This may be a pamphlet in four pages (in 2 col.), a reprint from the article in Le Radical, Brussels, of which no copy is known. Bronterre O'Brien met Buonarroti in Paris: "I have seen that brave and venerable old man... shed tears like a child at the mentioning of Robespierre's name" (A Dissertation and Elegy on the Life and Death of the immortal Robespierre, London, 1859, p. 7). The meeting must have taken place between May 1836 and September 1837 , when Buonarroti died at the age of 76 .

3 Daniel Guérin's important book La lutte de classes sous la Première République, 2 vol., Paris 1946 , is an elaborate refutation of this thesis.

4 Georges Lefebvre, Questions agraires au temps de la terreur, 2me édition, La Roche-surYon, 1954. His conclusion about the laws of Ventôse seems decisive: "il ne resterait en substance qu'une mesure terroriste de plus" (p. 49). 
a policy, which faced the opposition of the other members of the Committee of Public Safety, the majority of the "Montagnards" and the Convention. Political and civil liberty in the view of Robespierre ought to be complemented by security for all members of society as far as their means of livelihood were concerned, and the right of property should be limited by the state. ${ }^{1}$ Liberty and the reign of virtue were, according to Robespierre, incompatible with the existence of the wealthy, and extreme inequality should be gradually abolished. Complete equality however he regarded as a dangerous illusion, and he had always opposed the "Loi Agraire", which he qualified in $x 792$ as "un absurde épouvantail". Once in power Robespierre opposed all movements to abolish the rights of property, and denounced the "enragés" and "Hébertistes" at the Convention and at the Jacobins "avec un courage et une persévérance au-dessus de tout éloge", to quote Mathiez. The difference between Robespierre's notion of property and that of Buonarroti corresponds to the difference between the welfare state and a communist society, between Rousseau's Republic of Virtue and the "Cite Morellyste".

Although the propaganda of the Babouvists had a certain success - there was great discontent amongst the people and the Committee was even sometimes anxious to slow down the agitation as all the meticulous preparations for the insurrection were not yet finished the real support of the masses was lacking. The arrest of the Committee on the isth May brought little reaction from the people. The latter, despite their discontent and their disillusion with the course taken by the Revolution, had lost interest in political changes, and only took seriously the economic situation which was worse than a long time since 1789 . In fact, after Prairial the people were to take no further part in the successive "coups d'état" and changes of regime for 35 years, until in July 1830 they reappeared on the political scene. During the days of Prairial and even more so during Vendémiaire, the army had for the first time decisively intervened in the internal struggles and from these days onwards no one was able to govern France against the army, and soon afterwards only with it.

If the insurrection had been successful it would have been not so much the result of a popular movement as of a "coup d'état", even

${ }^{1}$ In Robespierre's proposed Declaration of Rights of $24^{\text {th }}$ April I 793 , is stated: "Property is the right of each and every citizen to enjoy and to dispose of the portion of property guaranteed to him by law. Society is obliged to provide for the subsistence of all its members, either by procuring work for them or by ensuring the means of existence to those who are unable to work". The Constitution of 1793 formulated the right of property as the right appertaining to every citizen to enjoy and dispose at will of his goods, his income, and the product of his labor and skill. 
though openly announced. The immediate aims of the conspirators were mainly those which had been proclaimed by the "enragés", and Daniel Guérin is certainly right in calling Babeuf an "enragé à retardement"; in fact this applies to the whole conspiracy: there existed no popular movement as in 1793 to support these aims. The downward trend of the Revolution had not begun at Thermidor, but in the months preceding it. At the end of $\mathrm{x} 793$ the Revolution had been arrested in its development, and the Government became more and more centralized and the revolutionary "sansculottes" became the victims of the Jacobin Terror. The Commune, the centre of revolutionary initiative since the roth August 1792, became the instrument of the Government instead of influencing its policy. Members were no longer elected but nominated, and the members of the Commune were transformed into salaried officials of the Government. In March 1794 the Commune was crushed. The sections of Paris who had played the essential part in the revolutionary organisation of the capital and the popular societies became gradually a machinery of the centralized power. Their death was the death of the Revolution. All the organs of the democratic Revolution were thus destroyed. After the liquidation of the "enragés", the "Hébertistes" were brought to the guillotine: in them, however, the popular masses had found the representatives of their social hopes and desires, and with their liquidation the Revolution had lost its impetus. The Thermidor only accelerated the downward trend. ${ }^{1}$ The new "bourgeoisie" was no longer prepared to accept the Terror when the Republic, thanks to the military victories, was no longer threatened. The social and economic policy of the Revolutionary Government had alienated the masses even more from the regime. The fixing of the maximum of salaries on the sth Thermidor was only the last step ${ }^{2}$, and four days later those who had been the "avantgarde" of the Revolution did not move to save Robespierre nor the regime. Amongst the Babouvists it was obviously only the "Hébertiste" Bodson, a former member of the Commune of "Io Août" and one of the agents of Babeuf's Committee, who had a clear view of the political situation. He rejected Babeuf's opinion that Robespierre and Robespierrisme was a rallying point for all opponents of the regime, and held that those men were responsible for the demoralisation of the people: "nous ne devons point oublier que si sous le gouvernement révolutionnaire le peuple était plus heureux, toujours est-il vrai qu'il fut dépouillé de toute sa souveraineté, en ne pouvant même pas nommer directement un commissaire de bienfaisance, en voyant

1 See the concluding chapters of Peter Kropotkine: The Great Revolution, London, 1909.

2 Sec G. Rude et A. Soboul, Le maximum des salaires parisiens et le 9 Thermidor, in:

“Annales Historiques de la Révolution Française", January-March 1954, p. 1-22. 
destituer les hommes qu'il s'était choisis, et qui avaient encore sa confiance, quoiqu'à l'époque où fut installé ce gouvernement, le peuple donnât la plus haute idée de ce que pouvaient faire sur lui les institutions démocratiques par les vertus et les actes de civisme qui commençaient à se propager et à germer dans tous les coeurs". ${ }^{1}$

The immediate measures to be taken by the Revolutionary Government were the lodging of the poor in the houses of the enemies of the people, the free restitution of the effects of the people, pledged at the "monts-de-piété" and the free distribution of clothes and bread. Another measure to be announced was the distribution of the property of emigrants and suspects to the soldiers and the poor, in other words the implementation of the laws of Ventôse. This was of course difficult to combine with the idea of the community of goods, and the arguments of Buonarroti in this respect are vague and of a purely opportunist nature. "The great point, he explained, was to succeed, and therefore one should neither practice too much reserve, which might possibly discourage one's true friends, nor too much precipitation, which would only increase the number of one's enemies".

In the opinion of Buonarroti it was not so much in order to preserve, but to establish equality amongst a "corrupt nation" that a dictatorship was needed. Buonarroti has given a precise account of the discussions and the reasons which led to this decision. To summon the primary assemblies immediately in order to constitute a legislative body and a Government would not be without danger. The time to elapse before the installation of the new authorit: should, however, be longer than the time strictly required by th. elections. The great lesson of the experience of the French Revolution was, that the best laws could not work as long as inequality existed. An assembly based on universal suffrage could not work immediately, because the people, so long estranged from the "natural order" of things and whose opinions had been formed under the regime of inequality, was poorly qualified to exercise its sovereignty and to distinguish wisely by its votes between the men most capable to direct it with success on the path to equality. The basic idea of Buonarroti's thought was that the sovereignty of the people and democracy could only function in a society where private property was abolished. Hence the necessity of a revolutionary and provisional authority to withdraw the people for ever from the influence of the natural enemies of equality, through the agency of some "wise and courageous citizens". At the beginning of a revolution it would therefore be less important to base the Government on the consent of the people according to universal suffrage than to make sure

1 In a letter to Babeuf, Copie des Pièces, II, p. I 56. 
that the Government would fall into hands that were "wisely and vigorously revolutionary". The delicate question how and by whom this dictatorship should be exercized, was, relates Buonarroti, scrupulously examined by the Committee. Two members of the Committee, Debon and Darthé, mindful of the disastrous consequences of plurality of which there were so many proofs in the divisions of the Committee of Public Safety, advocated a personal dictatorship. It is not quite clear if Buonarroti shared this opinion, although in the Conspiration ( 1828 ) he remarked that, if a man like Robespierre had been dictator, the purpose of the Revolution would have been accomplished. And in his Observations sur Maximilien Robespierre, written some years later, he remarked: "Would that Robespierre had been a dictator! Happy would it have been for France - happy for humanity, had Robespierre been sole dictator and sole reformer". But the difficulty of the choice, the possible abuse of power, the resemblance to monarchy and the general prejudice against this, induced the Committee to prefer control by a small group. The Committee, Buonarroti relates, was well aware that complete equality could not be accomplished at once the day after the insurrection, by a magic stroke or an act like the Creation. Equality would develop gradually and the date of achievement would depend upon the progress of opinion, so that it was not possible to predict when the "mission of the reformer" would have been completed.

It is an astonishing thing that the Committee, whilst preparing the insurrection, was discussing at the same time detailed plans for the organisation of the communist society and elaborate measures to achieve it. In the words of Buonarroti "the Committee never ceased to occupy itself with the definite legislation of equality, and with the intermediary laws by which it was to be gradually attained". Unfortunately most of the documents of this long term programme, "the most secret thoughts of the Committee" 1 have been lost, but from Buonarroti's story ${ }^{2}$ one gets a fair impression of their aims. The most essential document which has been preserved is a fragment of an economic decree. ${ }^{3}$ The author is probably Buonarroti and Robiquet was right in calling him "le théoricien et l'organisateur du mouvement des Egaux". ${ }^{4}$

I Just as in Buonarroti's secret societies "the most secret thoughts" were known only by the highest grade.

2 Conspiration, I, p. 206-296.

3 The document is amongst Buonarroti's papers in the Bibliothèque Nationale, N.A. 20803, fol. II 7-121, and reprinted with a few changes in the Conspiration, II, p. 305-319. 4 Robiquet, op. cit., p. I87; also M. Dommanget, Pages Choisies, op. cit., p. 14: "Buonarroti fut, avec Babeuf, le grand théoricien et le véritable législateur des Egaux". 
The Revolutionary Government would start by organising a "national community" which would hold all the properties of the "biens nationaux" not sold by the $9^{\text {th }}$ Thermidor; the property of the enemies of the Revolution which ought to have been appropriated according to the laws of Ventôse; all public buildings and properties of the communes and public corporations like hospitals etc. To this would be added the property of any citizens who voluntarily handed over their possessions. The national community would provide for the needs of all. The Government and the local administration would regulate and allot employment. Transport would be taken over by the Government. Foreign commerce would be a state monopoly. All products would be deposited in national stores. Labour would be directed where it was required. Private property and inheritance would be abolished, as well as money. There would be equal education for all. For some time however, there would be a private sector, but those who refused to join the community would be heavily taxed and the example of national community, the abolition of inheritance and general education would result in a disappearance of the private sector.

Once a certain degree of equality had been attained through the measures of the dictatorial Government, the sovereignty of the people would be re-established and universal direct suffrage restored, according to the constitution of $\mathbf{x} 793$. The primary assemblies of that Constitution, now called "Assemblée de Souveraineté, would not only have the right of veto on certain laws, as was laid down in the Constitution of 1793 , but also the main legislative initiative. Thus the people would take part in the legislative power and direct legislation would be established. The National Assembly now called "L'Assemblée Centrale des Législateurs" would have much less influence and the task of the Government would be merely an administrative one. In addition there would be established a "corps de conservateurs de la volonté nationale", a kind of tribunate 1 , which would proclaim the laws and watch over the legislators. The members of this tribunate would also be elected by the people from the Senates - composed of elderly men nominated by the local assemblies - but as these magistrates whose task it was to conserve the established equality would be incapable of establishing it, in the beginning their posts would have to be confined to the revolutionaries, just as the majority of the National Assembly would be nominated by the insurrectionalists. The sovereign power was to be rendered to the people only gradually, "et en raison du progrès des moeurs". Until then it could only be the wisest and

1 Morelly, in his Code de la Nature spoke of a "Sénat Suprême". 
most ardent advocates of reform, who could create a popular republican spirit.

The idea that the sovereignty of the people could only be established after the necessary reforms had been put through by a dictatorial Government composed of "sage and devoted revolutionaries", was to be the essence of Buonarroti's political ideology for the next forty years.

When in 1828 Buonarroti published his famous book in which he gave a detailed narrative of the plot, its conspirational methods, the revolutionary dictatorship and its equalitarian aims, the book caused not only a revival of the Jacobin tradition under the July Monarchy, but also introduced for the first time the ideology of state communism and dictatorship in the history of European socialism. Through his secret societies during the Empire and the Restoration and under the July Monarchy Buonarroti had kept these ideas alive. With regard to Buonarroti's book the neo-Babouvist Savary wrote: "Cet ouvrage... qu'il a distribué lui-même à ses amis depuis son retour en France, a contribué, disons mieux, a formé le parti communiste; car, ce qu'on ne sait pas assez, c'est qu'à l'époque où les doctrines communistes furent rendues publiques, lui et un certain nombre d'hommes admis dans son intimité, travaillaient depuis longtemps à les répandre". ${ }^{1}$

Republicans and socialists like Cabet were influenced by it, although Cabet rejected the insurrectional method as well as the dictatorship. "Je fus un des premiers patriotes qui, à son retour de l'exil, reçurent de lui son Histoire de la Conspiration de Babeuf comme témoignage de son estime". 2 "Nous dirons seulement que cet ouvrage, dont nous adoptons presque tous les principes ... nous sommes profondément convaincus qu'une minorité ne peut pas l'établir par la violence". ${ }^{3}$

Marx and Engels intended to publish a German edition, to be translated by Moses Hess, and through Marx, who read the book in I 844, it had a lasting influence on Marxist ideology. Bronterre O'Brien, the ablest of all the Chartist leaders ${ }^{4}$, was deeply influenced by it. It was mainly through Blanqui that the Babouvist tradition established itself under the name of Blanquism in the theory of socialism and the labour movement. Blanqui had certainly known Buonarroti - as one of the prominent members of the "Société des Amis du Peuple" in I830 he was in close contact with Raspail and

1 La Fraternité de I 845, p. 37-38.

2 Cabet, Toute la Vérité au Peuple, 1842, p. 85.

3 Cabet, Histoire populaire de la Révolution Française, Paris, 1840, p. 333-334.

4 G. D. H. Cole, Chartist Portraits, London, 1941, p. 266. 
Trélat, who belonged to Buonarroti's intimate circle. He played a dominant part in the secret republican revolutionary organisations under the July Monarchy. It was Blanqui who developed the technique of the insurrection as a military art and raised this method to a revolutionary theory: The conquest of political power by a disciplined revolutionary minority to establish the dictatorship. Not only the idea of a provisional dictatorship, but also the arguments for it are derived from Buonarroti. After the revolution in 1848 Blanqui - "le Marat de ces temps-ci", as George Sand once called him - opposed the holding of general elections, because - so ran his argument - the result could only be a victory of the reactionary provinces over Paris. A people subjected to fifty years of control by reactionary forces including the church - "ces populations asservies", in other words Buonarroti's "corrupt nation" - would be unable to vote for their own interests. He regarded the precipitate appeal to the electorate in 1848 as calculated treason. To prepare real political democracy, education of the people was necessary and this could only be done by a dictatorship. "Un an de dictature parisienne en 48 aurait épargné à la France et à l'histoire le quart de siècle qui touche à son terme. S'il en faut dix ans cette fois, qu'on n'hésite pas. Après tout, le gouvernement de Paris est le gouvernement du pays par le pays, donc le seul légitime. Paris n'est point une cité municipale, cantonnée dans ses intérêts personnels, c'est une véritable représentation nationale". ${ }^{1}$ Blanqui's Government of a "dictature parisienne" is therefore nothing else than the Babouvist Revolutionary Government nominated by the people of Paris. ${ }^{2}$

According to Buonarroti the dictatorship was necessary because the experience of the French Revolution had demonstrated that a people whose opinions have been formed under a regime of inequality and of despotism, is at the beginning of a revolution unfitted to distinguish wisely by its votes the men most capable of directing it with success. This task could belong only to certain wise and courageous citizens. Elsewhere Buonarroti formulated more precisely this idea as follows: "Il faut ... que la même volonté dirige l'affranchissement et prépare la liberté ... au commencement d'une révolution l'autorité suprême ne doit pas être déléguée par le choix libre du Peuple... Qui donc pourra exercer utilement le droit de désigner les hommes auxquels l'autorité révolutionnaire suprême doit être confiée? Ceux qui sont embrasés de

1 Auguste Blanqui, Critique Sociale, 1885, I, p. 208 (written x 868-x 870).

2 The first decree to be passed by the National Assembly said: "Le peuple de Paris, après avoir terrassé la tyrannie, usant des droits qu'il a reçus de la nature, reconnaît et déclare au peuple français:..." (Conspiration, I, p. I 57 ). 
l'amour de l'égalité et ont le courage de se dévouer pour en assurer l'établissement..." 1

Blanqui however shared neither Buonarroti's interpretation of the Revolutionary Government nor his opinion on Robespierre, and the atheist Blanqui detested Robespierre's state cult of the Supreme Being. ${ }^{2}$ Nor was he interested in blueprints of how a communist society should be organised after the conquest of power. Nor, by the way, was Marx, whose Utopia of a classless and stateless society was based on a utopian dialecticism of the historical process. Marx and Engels, however, never shared the Blanquist idea that a minority should conquer the state at any given moment, but they took over his idea of a revolutionary dictatorship, which however should be the dictatorship of a proletarian class and established as a result of the unevitable class struggle in capitalist society.

Through the German secret societies in France in the eighteenthirties, on which Buonarroti's direct influence is to be traced, and which were linked up with the Blanquist republican secret organisations, these ideas were not unknown to the Communist League for which Marx wrote his famous Manifesto. Members of the secret German "League of the Just" "3, who participated in the Blanquist insurrection of the I 2 th May 1839 - of which the "Rapport fait à la Cour des Pairs" declared: "C'est la conspiration de Babeuf passée de l'état de projet insensé à une sanglante exécution" - were expelled or had fled from Paris, and they worked in London in close contact with the Blanquist Société Démocratique Française, which advocated the dictatorship.4 In his article on the revolutionary events in France in the Neue Rheinische Zeitung in 1850 Marx used for the first time the phrase: dictatorship of the proletariat, and in the statutes of April i 850 of the

\footnotetext{
1 A manuscript of Buonarroti; published by A. Saitta, Filippo Buonarroti. Contributi alla storia della sua vita e del suo pensiero, Roma, I95 I, II, p. 137.

2 The Blanquists in the second half of the I 9 th century regarded themselves much more as the heirs of the "Hébertistes" than as followers of Robespierre.

3 The communist programme Weitling expounded in his book: Die Menschheit wie sie ist, 1839 (the influence of Cabet's Voyage en Icarie can be disregarded because the first edition appeared only a year later), written at the demand of the Central Committee of the "League of the Just", was the community of goods and labour of the Conspiration. In 1847, writing the first draft of the Communist Manifesto, Friedrich Engels still held the same opinion: private property had to be replaced by common ownership of the instruments of production and the distribution of all products based on the community of goods : „die sogenannte Gütergemeinschaft”,

4 C.f. A. Lehning, Discussions à Londres sur le communisme icarien, in: Bulletin of the International Institute of Social History, 1952, p. 87-109.
} 
shortlived I secret "Universal Society of Revolutionary Communists", founded by the Communist League, the French Blanquists in London and the Chartist Georg Julian Harney, it is stated: "Le but de l'Association est la déchéance de toutes les classes privilégiées, de soumettre ces classes à la dictature des prolétaires en maintenant la révolution en permanence jusqu'à la réalisation du Communisme..." 2 In his wellknown letter to Weydemeyer of the sth March 1852 he formulated more precisely the political theory to which he and Engels were always to keep: That the class struggle - and the existence of classes - conditioned by certain phases of the historical evolution of production would necessarily lead to the dictatorship of the proletariat, and that this dictatorship would form the transition to the abolition of all classes and lead to a classless society. Even as late as 1875 in his criticism of the social democratic programme of Gotha, Marx stated ${ }^{3}$ that in the period of transition from capitalist to socialist society the state could take no other form than "the revolutionary dictatorship of the proletariat". When Eduard Bernstein half a century after the publication of the Manifesto started his "revision" of Marxism, the author of the "Voraussetzungen" criticized the Blanquist tendencies from which Marx had never freed himself, because the essence of Blanquism was not the secret society and its conspirational methods, not the "Geheimbündelei" as these depend on circumstances, but the belief in the creative power of the revolutionary state. ${ }^{4}$ After social democracy had in practice become Revisionist and Lassallean, the Blanquist-Marxist tradition was revived by the Leninist interpretation of Marx, and Blanquist practice was taken over by the Bolshewik party. Of course, in Marxism dictatorship forms an essential part in the empirical dialectical process, by which the economic contradictions of capitalism and its complement the class struggle would lead to the conquest of the state by the Proletariat and the establishment of the dictatorship of the Proletariat under which the means of production would be socialized and socialism, a classless and stateless society, would evolve. ${ }^{5}$

1 The split in the Communist League (September 1850) between Willich and Schapper, on the one hand, and Marx and Engels on the other, made also an end to this society, which probably existed only on paper.

2 The statutes of six points were signed by Marx, Engels, Willich, Harney, Adam and Vidal. The original document is in the Marx-Engels Archives in the International Institute of Social History.

3 Engels still held the same opinion in 1890 .

4 E. Bernstein, Die Voraussetzungen des Sozialismus, Stuttgart, I899, Ch. II.; id., Blanquismo e Socialismo, Roma, 1899 .

5 In the Bolshewik theory and practice Buonarroti's wise and courageous citizens, who should exercise the dictatorship, are replaced by the so-called "avant-garde" of the Proletariat, i.e. the Bolshewik Party. 
Here then is Buonarroti's essential contribution to the European socialist tradition based on his experience in 1796 : the establishment through conspiratorial methods of a political dictatorship, a Babouvist committee of public safety to prepare an equalitarian regime. As has already been pointed out ${ }^{1}$ Buonarroti's conception of a revolutionary dictatorship which he held in the years before and after 1830 is neither that of a party nor of a class. Besides the theory of a revolutionary dictatorship as a transition to a communist society, there is nothing in the social ideas of Buonarroti which links them to the Marxist point of view. Nothing in fact could be further from Buonarroti's thinking than the Saint-Simonian idea of Marx concerning the development of industrial forces; of Marx' great praise of capitalism and his dialectical association of socialism with industrial development. Buonarroti's basic social ideas of $179^{6}$, his communism of goods and labour, never changed and their consistency can be traced through the scarce documents of his Secret Societies. It is not surprising that when, in the late twenties, he became acquainted with Owen's ideas, he admitted the identity of Owen's communities with his own conceptions, disagreeing only on the means of realising their mutual aim.

Babeuf attempted, wrote Buonarroti, the moulding of a large population in a single community; Owen wanted to increase the number of small communities in a country. Babeuf wished his friends to seize the supreme authority, as by its influence he hoped to effectuate the reform they had projected; Owen calculated on success by preaching and by example. May he show to the world that wisdom can operate so vast a good without the aid of authority. ${ }^{2}$ But to establish "cette douce communauté" Buonarroti kept to his "gouvernement révolutionnaire des sages." "Il est évident qu'une entreprise si importante et si délicate ne peut être tentée et favorisée qu'à l'aide de l'autorité parce qu'il n'y a que l'emploi de la force qui puisse entraîner les irrésolus et contenir les récalcitrans... C'est donc à renverser l'ordre d'égoïsme, à faire passer l'autorité en des mains dévouées à l'égalité, que les hommes vertueux doivent consacrer avant tout leurs pensées et leurs efforts." 3

In the last resort Buonarroti, with his religious and social beliefs, his deism and "natural religion", his equalitarianism, his humanism and universalism, was a man of the eighteenth century and the Enlightenment. His moralistic socialism was based on virtue. In his social

1 C.f. Buonarroti and his international secret societies, in this Review, vol. I, p. II6. In Buonarroti's conception the revolutionary dictatorship was linked up with the occult leadership of his secret societies.

2 Conspiration, I, p. 296.

3 Conspiration, ed. 1842 , p. $95-97$. 
philosophy there is no place for the concept of industrial development to procure a higher standard of living. His conceptions of a communist society are based on Morelly. From Adam Weisshaupt he might have inherited the idea of a secret leadership to lead the world to reason and liberty. The tremendous experience of the Revolution had convinced him that civil and political rights were not enough to build up a "société à cet état d'égalité et de liberté auquel se réduit en dernière analyse le grand bonheur de tous". Without social equality there could be no liberty. Robespierre's Revolutionary Government had taught him how a centralized political dictatorship could be used to establish "l'égalité de fait". His ultimate credo is formulated in the shortest way in his words: "La Liberté est une partie de la justice; la justice tout entière est dans l'égalité; la liberté sociale ne peut se concevoir sans l'égalité".

To reconcile liberty and equality - the problem which is the essential legacy of the Great Revolution and which is far from being solved by the modern world - this was the task to which his life was devoted. 